\title{
Kimya Öğretmen Adaylarının FeTeMM Uygulamaları Hakkındaki Görüşlerinin
}

\section{Incelenmesi*}

\section{Ayşegül TARKIN-ÇELİKKIRAN ${ }^{\dagger}$ ve Sevgi AYDIN-GÜNBATAR}

Öz: Bir durum çalışması olan bu araştırmada, bütünleşik Fen, Teknoloji, Mühendislik ve Matematik (FeTeMM) eğitimi yaklaşımı temel alınarak hazırlanan dört farklı etkinliğin uygulanmasına katılan 13 Kimya öğretmen adayının FeTeMM eğitimi etkinlikleri hakkındaki görüşlerinin değerlendirilmesi hedeflenmiştir. FeTeMM eğitimi etkinlikleri uygulamasında Wheeler, Whitworth ve Gonczi (2014) tarafından önerilen mühendislik tasarım süreci modeli kullanılmıştır. Altı hafta süren uygulamalar boyunca her etkinlik sonrasında katılımcılardan FeTeMM eğitimi etkinliklerinin kendilerine sağladığı katkılar, etkinliklerin en öğretici kısmı ve en zor kısımları hakkında yansıtma raporu (reflection papers) yazmaları istenmiştir. Veriler içerik analizi, betimsel analiz ve sürekli karşılaştırmalı analiz teknikleri ile analiz edilmiştir. Katılımcılar FeTeMM eğitimi uygulamalarının disiplinler arası bakış açısı kazandırma ve kimya alan bilgisi/öğrenilenleri hatırlama/pekiştirme noktasında önemli katkılar sunduğunu belirtmişlerdir. Özellikle tasarımın yapılmasına yönelik yapılan araştırma ve bunun sonucunda tasarım yapma basamaklarının en öğretici noktalar olarak belirtmişlerdir. Son olarak, öğretmen adayları özellikle kullanılacak malzemelere, ürünün nasıl tasarlanacağına karar verme ve gerekli bilgiyi edinme-

\footnotetext{
${ }^{*}$ Bu çalışmada kullanılan etkinlikler araştırmacılar tarafından tasarlanmış olup, izin alınıp referans verilerek kullanılması gerekmektedir.

† Yrd.Doç.Dr.Ayşegül TARKIN ÇELIKKKIRAN, Yüzüncü Yıl Üniversitesi, Eğitim Fakültesi, Matematik ve Fen Bilimleri Eğitimi Bölümü, Kimya Öğretmenliği ABD, aysegultarkin@yyu.edu.tr, Orcid ID:0000-0003-4379-3031

* Doç.Dr. Sevgi AYDIN GÜNBATAR, Yüzüncü Yıl Üniversitesi, Eğitim Fakültesi, Matematik ve Fen Bilimleri Eğitimi Bölümü, Kimya Öğretmenliği ABD, sevgiaydin@yyu.edu.tr, Orcid ID: 0000-0003-4707-1677
} 
araştırma noktasında zorlanmışlardır. Elde edilen bulgular 1şığında öğretmen eğitimi ve FeTeMM eğitimi uygulaması ile ilgili öneriler sunulmuştur.

Anahtar kelimeler: Bütünleşik FeTeMM eğitimi, kimya öğretmen adayları, mühendislik tasarım süreci, durum çalışması

\title{
Investigation of Pre-service Chemistry Teachers' Opinions about Activities based on STEM
}

\section{Approach}

\begin{abstract}
In this case study, we aimed to determine 13 pre-service chemistry teachers' opinions about four activities prepared in light of Science, Technology, Engineering and Mathematics (STEM) integrated approach. In the application of the activities, design approach model suggested by Wheeler et al. (2014) was used. Through the activities taken six weeks, after each activity, participants were asked to write a reflection paper about the contribution of the activity, the most informative part of the activity, and the hardest part of the activity. The data were analyzed through content analysis, descriptive analysis, and constant-comparative method. Participants stated that activities provided important contributions regarding interdisciplinary view, and recalling chemistry subject matter knowledge and reinforcing them. They also specified that research for designing and design steps are the most informative steps. Finally, they mentioned that it was hard to decide the materials used, decide how to design, and research for necessary knowledge. Implications for STEM education to pre-service teachers were provided in light of the results.
\end{abstract}

Keywords: Integrated STEM education, pre-service chemistry teachers, engineering design process, case study 


\section{Kimya Öğretmen Adaylarının FeTeMM Uygulamaları Hakkındaki Görüşlerinin İncelenmesi}

\section{Giriş}

Yaşadığımız yüzyılda bilimsel ve teknolojik bilgiyi hem günlük hayatında kullanabilen hem de bunları yeni ürünler tasarlarken uygulayabilen insan gücüne ihtiyaç duyulmaktadır (Kennedy ve Odell, 2014). Özellikle küresel ekonomik yarışta, bu tür insan gücüne duyulan ihtiyaç her geçen gün artmaktadır (Ulusal Üniversiteler ve İşverenler Derneği [National Association of Colleges and Employers, NACE], 2015; Sanders, 2009). Artan ihtiyaca karşın, Amerika Birleşik Devletleri'nde (ABD) yapılan çalışmalarda üniversitede fen, teknoloji, mühendislik ve matematik (FeTeMM) alanlarını meslek olarak tercih edenlerin sayısının gün geçtikçe azaldığı ortaya konulmuştur (National Research Council [NRC], 2012). Bu azalma göz önünde bulundurulduğunda bilimsel ve teknolojik bilgiyi kullanabilen ve uyarlayabilen insan gücü bulmakta zorluk yaşanması beklenilen bir durumdur. Küresel yarışta bilim ve teknolojinin öneminin her geçen gün arttığı günümüzde, özellikle ABD’nin bu yarışta lider olma isteği ve günümüzde karşılaştığımız problemlerin tek bir alana ait bilgiler ile çözülememesi (Stohlmann, Moore ve Roehrig, 2012) FeTeMM yaklaşımının ortaya çıkış noktasıdır. Dünya'da özellikle ABD'de, Avrupa'da ve Avustralya'da karşılaşılan bu sorunların ülkemizin de sorunu olup olmadığının incelendiği STEM (FeTeMM) Eğitimi Türkiye Raporu'nda (Akgündüz vd., 2015) Türkiye'de de benzer sorunlar baş gösterdiği ortadadır. Dolayısıyla, FeTeMM eğitimi nedir, nasıl olmalıdır ve öğretmenlerin FeTeMM eğitimi açısından yetiştirilmesi şu an için özellikle alan eğitimcilerinin odaklanması gereken esas noktalardır (Tezel ve Yaman, 2017). "Eğitim fakültelerinde öğretmen adaylarının FeTeMM becerilerini artırmaya yönelik-mühendislik ve fen edebiyat fakültesiyle işbirliği içinde - çalışmalar yapılmalı, projeler geliştirilmeli ve hizmetiçi 
eğitim modülleri oluşturulmalıdır.” (Tezel ve Yaman, 2017, s. 142). Bu ihtiyaçtan hareketle, bu çalışmanın amacı kimya öğretmen adaylarına farklı disiplin ve alanların bir arada öğretimini ve uygulamasını vurgulayan Fen, Teknoloji, Mühendislik ve Matematik alanlarının baş harfleri ile oluşturulan bütünleşik FeTeMM (STEM: Science, Technology, Engineering and Mathematics) eğitimi konusunda verilen altı haftalık eğitim sonunda/sürecinde öğretmen adaylarının FeTeMM eğitimi ile (FeTeMM eğitimi etkinliklerinin kendilerine sağladığı katkılar, etkinliklerin en öğretici kısmı ve en zor kısmı) ilgili görüşlerini ortaya koymaktır.

\section{Alan Yazın Taraması}

\section{FeTeMM Yaklaşımının Çıkış Noktası}

Bütünleşik FeTeMM eğitiminin çıkış noktasında küresel güç yarışında özellikle Çin, Rusya ve Hindistan gibi ülkelerle yarışta olan ABD’nin bu yarışta daha üstün olma motivasyonu etkili olmuştur (Sanders, 2009). Diğer bir nokta ise, özellikle yine bu motivasyonla ilgili olarak ABD’de FeTeMM alanlarını seçen öğrenci sayısındaki düşüş bu yaklaşımın çıkışında önemli rol oynamıştır. $\mathrm{Bu}$ durum $\mathrm{ABD}$ dışındaki diğer ülkelerde de gözlenmektedir. Örneğin, Avustralya'da zorunlu eğitim sonrası fen ve matematik ile ilgili alanları seçenlerin sayısında düşme bulunmaktadır. Bissaker (2014) bu düşüşü öğretim programlarının günlük hayattan soyutlanmış olmasına, öğrencilerin bu alanlara karşı olumsuz tutumuna ve kaliteli öğretmen azlığına bağlamaktadır. Diğer ülkelerde karşılaşılan bu sorunların ülkemizin de sorunu olup olmadığının incelendiği STEM (FeTeMM) Eğitimi Türkiye Raporu'nda belirtildiği üzere (Akgündüz, vd., 2015) Türkiye'de de benzer sorunlar baş göstermektedir. Türkiye Raporu'nda verilen rakamlara göre 2000-2014 yılları arasında üniversite sınavında ilk 1000'e giren öğrencilerin FeTeMM alanlarını (Tıp Fakültesi hariç tutulmuştur) tercih etme oran $\% 85,63$ 'ten 2014 yılında \%38,23’e düşmüştür. FeTeMM eğitiminin dikkat çektiği diğer bir nokta ise FeTeMM alanlarının kız ve erkek öğrenciler tarafından yaklaşık 
oranlarda tercih edilmemesidir. Ülkemizde de yine benzer problem rakamlar ile ortaya konmuştur. FeTeMM alanlarını tercih eden ve ilk 1000'de yer alan sayısal bölüm öğrencileri arasında erkeklerin oranı \%81,39 iken kızların oranının \%18,61 olduğu ortaya çıkmıştır. Gelişmiş ülkelerin eğitim politikalarında gündemi yoğun şekilde meşgul eden FeTeMM öğretiminin ortaya çıkma nedenlerinin birçoğu- örneğin; FeTeMM alanlarının tercih edilme oranındaki düşüş, erkek ve kız öğrencilerin FeTeMM alanlarını tercih etme oranları arasında büyük fark olması ve FeTeMM alanlarında istihdam edilmiş insan gücünün azlığı nedeni ile küresel güç yarışında geri kalma kaygısı ülkemizin de problemleri arasındadır.

\section{STEM Kısaltmasının Evrimi: SMET'ten STEM'e}

STEM kısaltması aslında günümüzde Amerika Birleşik Devletleri ile birlikte birçok ülkede eğitimcilerin gündeminde yer alan, öğretim programlarına girmiş ya da girmek üzere olan, üzerinde çok konuşulan bütünleştirici, öğrenciyi etkin kılan, problem ve tasarıma dayalı bir yaklaşımdır. İlk olarak 1990'l1 yıllarda National Science Foundation (NSF) tarafindan farklı bir kısaltma ile kullanılmaya başlanmıştır: Science, Mathematics, Engineering, Technology (SMET) (Sanders, 2009). İlerleyen zamanlarda SMET kısaltmasının İngilizce söylenişinin sanki ‘kurum’ ya da 'is’ anlamına gelen 'smut' şeklinde olmasını eleştiren NSF yetkilisinin eleştirisi ile STEM olarak kullanılan kısaltmaya geçiş olmuştur (Sanders, 2009). Ülkemizde hem STEM hem de FeTeMM kısaltmaları yaygın olarak kullanılmaktadır. Ancak yine bu noktada dikkat edilmesi gereken bir diğer husus ‘STEM Eğitimi’ ya da 'FeTeMM Eğitimi’ şeklinde kullanılmasının gerekliliğidir.

\section{FeTeMM Eğitimi Yaklaşımı Ne Anlama Gelmektedir?}

FeTeMM eğitimi denildiğinde maalesef farklı kişiler farklı tanımlar ortaya koymakta ve dolayısıyla farklı yorumlar ortaya çıkmaktadır (English ve King, 2015). "FeTeMM kısaltması, bu alanda çalışanlar için bile muğlak bir kısaltmadır" (Sanders, 2009, s. 20). Bu durumda 
uygulamalarda farklılıklara yol açmaktadır. Buradan hareketle, öncelikle FeTeMM eğitiminin ne olduğunun ortaya konulması gerekmektedir. "Bizim FeTEMM'e bakış açımı, FeTeMM alanlarından iki ya da daha fazlasının, ya da bir FeTeMM alanı ve bir ve/veya bir kaç okul dersinin öğretimini ve öğrenilmesini inceleyen yaklaşımları kapsamaktadır” (Sanders, 2009, s. 21). Bir başka tanım ise "fen, teknoloji, mühendislik ve matematik alanlarını bir derste bu alanlar arasındaki bağlantılar ve gerçek yaşam problemleri sayesinde birbirine bağlamaya çalı̧̧an bir gayret” (Stohlmann vd., 2012, s. 30) olarak ortaya konulmuştur. Burada Stohlmann ve arkadaşlarının dikkat çektikleri bir nokta ise bu dört farklı ancak birbiri ile ilgili alanın her etkinlik ya da derste bir arada zorunlu olarak bulunması gerekmediğidir.

FeTeMM eğitimi için oluşturdukları teorik modelde özellikle "Mühendislik Tasarım Süreci” (engineering design) bütünleşik FeTeMM eğitimi için uygun bir bağlam oluşturmaktadır ve bu bağlam fen ve matematik konularının öğretiminde rahatlıkla kullanılabilmektedir (Kelley ve Knowles, 2016). Özellikle ABD'de (NGSS, 2013), yeni fen eğitimi programlarında mühendislik tasarım sürecinin öneminin altı çizilmiş ve bu alanların birbiri ile bütünleştirilmesinin proje tasarlama ve günlük hayat problemleri çözme üzerine inşa edilmesi gerektiği vurgulanmıştır. Böylelikle mühendislik alanı ile diğer alanların koordineli bir şekilde öğrenmede rol alması sağlanmaktadır (Burrows, Breiner, Keiner ve Behm, 2014; Carmel, Ward ve Cooper, 2017).

\section{FeTeMM Öğretmen Ĕ̆itimi}

FeTeMM eğitimi yaklaşımı ülkemizde 2017 yılında ilk kez kullanılmaya başlanan yeni Fen Bilimleri öğretim programında "Uygulamalı Bilim" ünitesi olarak yerini almıştır. Bu durumun yapılan öğretim programı tanıtım sunusunda 5. bir öğrenme alanı olarak kabul edildiği belirtilmiştir (Milli Eğitim Bakanlığı [MEB], 2017). Bu yaklaşımın esasına uygun şekilde kullanılmasının ve öğrencilere doğru eğitimin verilmesinin en önemli ön koşullarından birisi öğretmen eğitimidir. $\mathrm{Bu}$ 
noktada hem eğitim fakültelerinde hem de hizmet içi eğitim programlarında öğretmenlere FeTeMM eğitimi konusunda gerekli teorik ve pratik eğitimin verilmesi bu eğitim açığının kapatılmasını kolaylaştıracaktır (Akgündüz, vd., 2015). Ancak bu açı̆̆ın ne tür bir eğitim modeli ile en iyi şekilde kapatılacağı henüz tam olarak yanıtlanmamıştır (Stohlmann vd., 2012, s. 28).

FeTeMM eğitimi faklı alanları ve bunların ilişkisini barındırdığı için klasik fen öğretmen eğitiminde olduğu gibi alan bilgisi ve pedagojik alan bilgisi gelişimi sağlamak için gerekli dersleri verip (örneğin, Özel Öğretim Yöntemleri, Ölçme ve Değerlendirme dersleri gibi) öğretmenlerin bu anlamda yeterli olacaklarını varsaymak yüzeysel bir yaklaşım olacaktır (Sanders, 2009). Öğretmenlerin disiplinler arası yaklaşım ile öğretim yapmasının önündeki en önemli engellerden biri bu tür bir eğitim için gerekli alan bilgisine sahip olmamalarıdır (Stinson, Harkness, Meyer ve Stallworth, 2009). Dolayısıyla, "FeTeMM eğitiminin temelleri, pedagojisi, öğretim programı, araştırmalar, FeTeMM alanlarının her birinde ele alınan güncel konular ve yeni bütünleşik FeTeMM fikirleri, yaklaşımları, öğretim materyalleri ve öğretim programları" (Sanders, 2009, s. 22) tanıtılmalıdır. Singapur'da özel FeTeMM okullarında çalışmış ve çalışmakta olan eğitimciler olarak deneyimlerini paylaştıkları çalışmada Teo ve Ke’ye (2014) göre öğretmen eğitimi programlarında öğretmen adaylarına sınıf ortamındaki uygulamalar ile ilgili olarak tanıtılması ve kazandırılması gereken önemli bir kavram ‘belirsizlik’tir (uncertainity). Sınıf ortamına girildiğinde birçok konuda belirsizliklerle karşılaşılabilineceği vurgulanmalıdır. Kendi deneyimlerinden yola çıkarak sundukları FeTeMM eğitimine ait problemlerden bazılarının altını çizmişlerdir. Bunlardan birincisi FeTeMM okullarında normal okullara göre daha fazla biçimlendirici değerlendirme kullanımıdır. Farklı proje ödevleri kullanmak ve bunlar için zaman ayırmak biçimlendirici değerlendirme sürecinde karşılaştıkları güçlüklerdendir. İkinci olarak FeTeMM okullarında verilen öğretimin gerçek hayata çok yakın ya da gerçek hayattan olmasıdır. Ancak Teo ve Ke'ye (2014) 
göre bitirmiş oldukları öğretmen eğitimi programı ise teoride kalmaktadır ve onları gerçek hayatı temel alan bir öğretim oluşturma açısından hazırlamakta yetersiz kalmıştır.

Stohlmann vd. (2012) FeTeMM öğretmenlerinin daha etkili olabilmeleri için destek (support), öğretim (teaching), yeterlik (efficacy) ve materyal (material) bileşenlerinden oluşan ve İngilizcesinin kısaltması STEM ve Türkçe kısaltması DÖYM olan modeli ortaya koymuşlardır. Destek bileşeni ile ilgili olarak, okul-üniversite ortaklığı önerilen bir stratejidir. ABD'de bu birlikteliği ve desteği sağlayan ve özellikle mühendislik ve tasarım süreci hakkında destek veren örnekler ön plana çıkarılmıştır. Ayrıca, hizmet öncesi öğretmen eğitimi programlarının özel öğretim yöntemleri dersinde özellikle alan/içerik entegrasyonunun sağlanması da öğretmenlere bu anlamda destek olarak ortaya konmuştur. DÖYM modeli ile Stohlmann vd., (2012) bütünleşik FeTeMM öğretiminin zaman, enerji, organizasyon ve bilgili öğretmenler ve eğitimciler gerektirdiğinin altını çizmişlerdir. Öncelikle hem kendi alanlarındaki hem de diğer alanlardaki alan bilgilerinin zenginleştirilmesi sağlanırken öğretmenlerin FeTeMM'e yönelik etkinliklerin kullanımı noktasında gelişimi yeterlik açısından desteklenmelidir. Bu noktada özellikle hem okulüniversite hem de farklı branşlardaki öğretmenlerin ortaklaşa çalışmaları, bu ortaklıkların okullar tarafından desteklenmesi ve hizmet-içi öğretmen eğitimlerine katılım FeTeMM uygulamalarının başarısını ve kalitesini belirlemektedir. Ayrıca, Stohlmann vd. (2012) bütünleşik FeTeMM öğretiminin araç-gereç ve malzeme gerektirmesi dolayısıyla bu noktada hem ortam hem de maddi olarak gereksinimlerden bahsetmişlerdir. Özellikle araştırma yapabilmek için sınıflarda bilgisayar ve internet ulaşımı, bazı yazılımlar ve donanımların satın alınması gereksinimi bu anlamda öğretmenlerin desteklenmesini zorunlu k1lmaktadır (Stohlmann vd., 2012).

Ülkemizde gerçekleştirilen çalışmalardan Bozkurt-Altan, Yamak ve Buluş-Kırıkkaya (2016) fen bilgisi öğretmen adaylarının laboratuvar dersinde aldıkları tasarım temelli fen eğitimini 
motivasyon arttırıcı, öğrenmeyi daha kalıcı hale getiren, düşünme becerisi kazandıran ve öğrenciye yaparak-yaşayarak öğrenme şansı veren bir süreç olarak değerlendirmişlerdir. Yine laboratuvar dersinde gerçekleştirilen başka bir çalışmada fen bilgisi öğretmen adayları bu tür etkinliklerin laboratuvarda kullanılması ile ilgili olarak fenin diğer alanlarla ilişkilendirilmesini örneklerle gördüklerini ve bu tür yaşantılarla günlük hayat problemlerini daha rahat çözebilir hale geldiklerini belirtmişlerdir (Gökbayrak ve Karışan, 2017a). Ayrıca, uygulanan eğitim sonrasında, deney grubu lehine son testte bilimsel süreç becerisi testindeki artışın istatistiksel olarak anlamlı olduğu ortaya konmuştur (Gökbayrak ve Karışan, 2017b). Benzer bir çalışmada, öğretmen adaylarına FeTeMM eğitiminin sunulduğu bir diğer bağlam ise Özel Öğretim Yöntemleri dersidir. Aslan-Tutak, Akaygün ve Tezsezen (2017) bu bağlamda kimya ve matematik öğretmen adayları ile gerçekleştirdikleri araştırmada küçük gruplar halinde dört hafta boyunca farklı etkinlikler gerçekleştirmişlerdir. Araştırmada katılımcıların FeTeMM eğitimi tanımları, FeTeMM eğitiminde kullanılacak en etkili yöntemler, bu alanlarda çalışan öğretmenlerin daha etkili olması için yapılacaklar ve FeTeMM eğitiminin devamını sağlayabilmeleri için ne tür desteğe ihtiyaç duydukları noktasındaki görüşlerinin alınması için araştırmacılar tarafından geliştirilen FeTeMM Farkındalığı Anketi çalışma başında ve sonunda uygulanmıştır. Öğretmen adaylarının eğitim sonrasında FeTeMM yaklaşımının bütünleşik doğasını daha iyi kavradıkları ve özellikle projelerin varlığında bir eğitimin altını çizdikleri belirlenmiştir. Son olarak, FeTeMM eğitimi projelerinde yer almak ve var olan projeleri incelemenin bu eğitim sonrasında ihtiyaç duydukları noktalar olduğunu belirtmişlerdir.

Özetle, yeni bir yaklaşım olan FeTeMM eğitimi yaklaşımını bilen, kullanabilen ve yeni etkinlikler tasarlama noktasında bilgili ve deneyimli öğretmen yetiştirebilmek adına henüz göreve başlamamış ve eğitim almakta olan öğretmen adaylarını donatmak atılacak en önemli adımların 
başında gelmektedir. Hem öğretmen adayı olarak bu eğitimden geçerken alan bilgisi ve pedagojik alan bilgisi olarak donatılmaları hem de daha sonra mesleğe başladıklarında bu deneyimlerini kullanmaları öğretim programlarında yapılan reformların hedefine ulaşmasında etkili olan en önemli değişkenlerden biridir (Bissaker, 2014; Cooper, 2013). Bu eğitimin alınması sırasında öğretmen adaylarının FeTeMM eğitimi etkinliklerinin kendilerine sağladığı katkılar, etkinliklerin en öğretici kısmı ve en zor kısmı hakkında ortaya koyduğu noktalar daha sonra organize edilecek benzer eğitimlerin yapılandırılmasına da 1şık tutacaktır. Bu noktada gerçekleştirilen bu çalışma alan yazına ve öğretmen eğitimcilerine önemli bilgiler sunacaktır.

\section{Yöntem}

$\mathrm{Bu}$ bölümde araştırmacılar tarafindan verilen FeTeMM eğitimine dair uygulama süreci, araştırmanın deseni, örneklemi, veri toplama ve analiz süreçleri ele alınmıştır.

\section{Uygulama Süreci}

Öğretmen adayları için hazırlanan FeTeMM eğitiminin altı haftalık içeriği Tablo 1'de belirtilmiştir.

Tablo 1

FeTeMM Ë̆itiminin Altı Haftalık İçeriği

\begin{tabular}{lll}
\hline Zaman & Uygulama & Amaç \\
\hline 1.Hafta & FeTeMM Eğitimi Yaklaşımının Tanıtımı & $\begin{array}{l}\text { FeTeMM eğitimi yaklaşımının amacı, } \\
\text { dayandığı temeller, çıkış noktası, } \\
\text { yaklaşımın ne olduğunun tanıtılması ve } \\
\text { mühndisliğin ne olduğunun tartışılması }\end{array}$ \\
\hline 2-3. Hafta & Soğuk Kompres Torbası Tasarımı & $\begin{array}{l}\text { Günlük hayatta sık kullanılan soğuk } \\
\text { kompres torbalarının belirtilen kriterlere }\end{array}$ \\
& & $\begin{array}{l}\text { uygun olarak kolligatif özellikler } \\
\text { ve/veya endotermik-ekzotermik } \\
\text { çözünme ilkeleri temel alınarak } \\
\text { tasarımının yapılması (Aydın-Günbatar, } \\
\text { Tarkın-Çelikkıran ve Demirdöğen, } \\
\text { 2017) }\end{array}$ \\
\hline
\end{tabular}


Tablo 1 (devamı)

FeTeMM Ĕ̈itiminin Altı Haftalık Içeriği

\begin{tabular}{|c|c|c|}
\hline Zaman & Uygulama & Amaç \\
\hline 4.Hafta & İndikatör Yapımı & $\begin{array}{l}\text { Günlük hayatta karşımıza çıkan ve bitki } \\
\text { ya da diğer malzemeleri kullanarak } \\
\text { geniş bir pH aralığında renk skalası } \\
\text { veren indikatör hazırlama. İkinci } \\
\text { aşamada bu indikatörün kullanımı ile pH } \\
\text { kâğıdı yapmak için uygun kâğıt } \\
\text { malzeme seçimi. Üretilen indikatör ve } \\
\text { pH kağıdının marka logosunun ve } \\
\text { reklam tasarımının yapılması }\end{array}$ \\
\hline 5.Hafta & Akvaryumdaki $\mathrm{CO}_{2}$ ölçümü & $\begin{array}{lrr}\text { Akvaryum ortamında } & \text { canlıların } \\
\text { yaşaması için gerekli } & \text { ortamın } \\
\text { sürekliliğinin sağlanması için suyun pH } \\
\text { değerinin sürekli kontrolünü sağlayan } \\
\text { bir sistemin tasarlanması }\end{array}$ \\
\hline 6.Hafta & Elmanın Kararmasının Önlenmesi & $\begin{array}{l}\text { Enzimatik bir reaksiyon olan elmanın } \\
\text { kararması reaksiyonunun fiziksel ve } \\
\text { kimyasal yöntemler kullanarak } \\
\text { yavaşlatılması için gerekli ortam ve } \\
\text { süreçlerin tasarlanması }\end{array}$ \\
\hline
\end{tabular}

FeTeMM eğitimi etkinliklerinin uygulanması sırasında Wheeler vd. (2014) tarafindan önerilen ve öğrencilerin mühendislik tasarım sürecini yaşamalarını sağlayan model kullanılmıştır. Tablo 2, modelde yer alan basamakları ve her bir basamakta öğretmenlerin öğrencileri nasıl yönlendirdiğini göstermektedir.

Tablo 2

Wheeler vd. (2014) Tarafindan Önerilen Mühendislik Tasarım Süreci Modeli

\begin{tabular}{ll}
\hline Basamaklar & Yönlendirici sorular \\
\hline Beyin fırtınası & $\begin{array}{l}\text { Problemi başarılı bir şekilde çözmek için aklınıza gelen her şeyi } \\
\text { not edin. Notlarınıza çizimlerinizi ve ihtiyacınız olan malzemeleri } \\
\text { de ekleyin. }\end{array}$ \\
\hline Araştırma & $\begin{array}{l}\text { Problemi çözmek için araştırma yapın. Araştırmak istediğiniz } \\
\text { soruları not edin. Öğrendiklerinizi not ettikten sonra birinci } \\
\text { basamağa dönerek başlangıçtaki düşüncelerinizde değişiklikler ve } \\
\text { eklemeler yapın. Ekleme ve değişiklikler için farklı renkte kalem } \\
\text { kullanın. }\end{array}$ \\
\hline
\end{tabular}


Tablo 2 (devam1)

Wheeler vd. (2014) Tarafindan Önerilen Mühendislik Tasarım Süreci Modeli

\begin{tabular}{ll}
\hline Basamaklar & Yönlendirici sorular \\
\hline Tasarım & $\begin{array}{l}\text { Problemin çözümü için ürettiğiniz tasarımınızı çizin ve ihtiyacınız } \\
\text { olan malzemeleri not edin. Bir sonraki basamağa geçmeden önce } \\
\text { tasarımınız için öğretmeninizden onay alın. }\end{array}$ \\
\hline Yapma ve test etme & $\begin{array}{l}\text { Malzemeleri kullanarak tasarımınızı yapın ve test edin. Verileri } \\
\text { toplayın ve tasarımınızın ne kadar etkili olduğunu değerlendirin. } \\
\text { Tasarımınızı geliştirmek için en az bir öneri yazın ve üçüncü } \\
\text { basamağa dönerek değişiklik ya da ekleme içeren önerinizi farklı } \\
\text { bir kalemle not edin. }\end{array}$ \\
\hline Tekrar tasarlama & $\begin{array}{l}\text { Yaptığınız testlere ve önerilerinize göre tasarımınızı tekrar test } \\
\text { edin ve yeniden yapın. Tasarımınızın son halini çizin. }\end{array}$ \\
\hline Değerlendirme & $\begin{array}{l}\text { Son tasarımınızı ilk tasarımınızla karşılaştırarak değerlendirin. } \\
\text { Tasarımınız gelişti mi? }\end{array}$ \\
\hline
\end{tabular}

\section{Araştırma Deseni}

FeTeMM eğitimi etkinliklerine dair öğretmen adaylarının görüşlerinin değerlendirilmesini amaçlayan bu araştırma nitel araştırma yöntemlerinden durum çalışması deseni esas alınarak yapılandırılmıştır. Durum çalışmaları bir bireyin, programın, kurumun veya ortamın değerlendirilmesi ya da derinlemesine ve detaylı çalışılmasını kapsamaktadır (Marshall \& Rossman, 2006; Merriam, 2013; Yıldırım \& Şimşek, 2011). Bu araştırmada incelenen durum, öğretmen adaylarının FeTeMM eğitimi etkinliklerine yönelik değerlendirmeleridir.

\section{Çalışma Grubu}

Uygulanan eğitimler sonucunda öğretmen adaylarının FeTeMM eğitimi etkinliklerine yönelik görüşlerini ortaya çıkarmak amacıyla 2016-2017 akademik yılının bahar döneminde bir üniversitenin Kimya öğretmenliği programının üçüncü sınıfında bulunan ve araştırmacılar tarafından verilen Özel Öğretim Yöntemleri-2 dersine kayıtlı olan 13 kimya öğretmen adayı (8 kız, 
5 erkek) ile yürütülmüştür. Katılımcıların isimlerini gizli tutmak için tüm isimler makale içerisinde değiş̧irilerek kullanılmıştır.

\section{Veri Toplama Aracı}

Öğretmen adaylarının FeTeMM eğitimi etkinliklerine ilişkin değerlendirmelerini ortaya çıkarmak için çalışmaya katılan öğretmen adaylarından her etkinlik sonrası aşağıda belirtilen sorulara cevap vermeleri istenerek yansıtma raporları (reflection papers) yazmaları istenmiştir. Öğretmen adaylarının hazırlamış oldukları raporlar etkinlikleri takip eden bir sonraki hafta dersin başında toplanmıştır.

1. FeTeMM eğitimi etkinliğini uygulamak size ne kazandırdı?

2. FeTeMM eğitimi uygulamalarının diğer yöntem ve stratejilerden farkı nedir? Siz bu uygulamaya katılmış biri olarak ne tür farklı deneyimler kazandınız?

3. FeTeMM eğitimi uygulamasında sizce en zor olan kısım neydi? Neden?

4. FeTeMM eğitimi uygulamasında en öğretici kısım hangisiydi? Neden?

5. FeTeMM eğitimi etkinliğine katılmak kimya konularını öğrenmenize etki etti mi? Nasıl? Hangi konu/konuları?

\section{Verilerin Analizi}

Yansıtma raporları içerik analizi, betimsel analiz ve sürekli karşılaştırmalı analiz teknikleri bir arada kullanılarak araştırmacılar tarafından analiz edilmiştir. İçerik analizinde verilerin birbirine benzerlikleri belirlenerek belirli kategori ve temalar çerçevesinde bir araya getirilir. Kategori ve temaların oluşturulmasında araştırmanın kavramsal çerçevesinden yola çıkılmıştır. Kategorilerin oluşturulmasında, her öğretmen adayının verileri sürekli karşılaştırma tekniği kullanılarak analiz edilmiş ve ortaya çıkan temalar isimlendirilmişsir. Çalışmada elde edilen verilerin yarısı araştırmacılar tarafından bağımsız olarak analiz edildikten sonra araştırmacılar 
arasındaki kodlama uyumluluğuna bakılmış ve yüksek oranda benzerlik bulunması sonucu verilerin diğer yarısı ilk yazar tarafından kodlanmıştır. Betimsel analizde de görüşülen bireylerin görüşlerini yansıtmak amacıyla doğrudan alıntılara yer verilmiştir (Yıldırım ve Şimşek, 2011).

\section{Bulgular}

Öğretmen adaylarının her etkinlik sonunda hazırladıkları yansıtma raporlarında etkinlikleri kendilerine neler kazandırdıkları açısından, etkinliklerin en öğretici ve en zor kısımları açısından değerlendirmeleri istenmiştir. Bu bölümde içerik analiz sonucunda ulaştığımız kategoriler ve temalara yer verilmiştir. Yansıtma raporlarının içeriğini oluşturan 1, 2, ve 5. sorulara verilen cevaplar "FeTeMM eğitimi etkinliklerinin öğretmen adaylarına sağladığı katkılar başlığı altında", 3. soruya verilen cevaplar "FeTeMM eğitimi etkinliklerinin en öğretici kısmı" başlığı altında ve 4 . soruya verilen cevaplar "FeTeMM eğitimi etkinliklerinin en zor kısmı" başlğ̆ altında incelenmiştir. İlgili başlıklara ait bulgular, analiz sonuçlarında ortaya çıkan tema ve kategoriler, çalışmada uygulanan etkinlikleri ve katılımcıları belirten tablolar halinde sunulmuştur. Ayrıca, bulgular sunulurken öğretmen adaylarının görüşlerini yansıtmak amacıyla doğrudan alıntılara yer verilmiştir.

\section{Öğretmen Adaylarının FeTeMM Eğitimi Etkinliklerinin Kendilerine Sağladığı Katkılara İlişkin Görüşlerine Yönelik Bulgular}

Öğretmen adaylarının tamamının görüşlerine bütünsel bir bakış sağlamak amacıyla Tablo 3'de uygulanan FeTeMM eğitimi etkinliklerinin katılımcılara sağladığı katkılara ilişkin bulgular sunulmuştur. 
Tablo 3

FeTeMM Ĕ̈itimi Etkinliklerinin Öğretmen Adaylarına Sağladı̆̆ Katkılara İlişkin Bulgular

\begin{tabular}{|c|c|c|c|c|c|c|c|c|}
\hline \multirow[b]{2}{*}{ Kategori } & \multicolumn{2}{|c|}{$\begin{array}{l}\text { Soğuk Kompres } \\
\text { Torbası Tasarımı }\end{array}$} & \multicolumn{2}{|c|}{ İndikatör Yapımı* } & \multicolumn{2}{|c|}{$\begin{array}{l}\text { Akvaryumdaki } \mathrm{CO}_{2} \\
\text { ölçümü* }\end{array}$} & \multicolumn{2}{|c|}{$\begin{array}{l}\text { Elmanın Kararmasının } \\
\text { Önlenmesi }\end{array}$} \\
\hline & f & Katılımeılar & f & Katılımcılar & f & Katılımcılar & f & Katılımcılar \\
\hline $\begin{array}{l}\text { Disiplinler arası } \\
\text { bakış açısı }\end{array}$ & 10 & $\begin{array}{l}\text { Zeynep, Rıfat, } \\
\text { Fatih, Irmak, } \\
\text { Tuğçe, Seher, } \\
\text { Nehir, Yağız, } \\
\text { Cenk, Mert }\end{array}$ & 1 & Seher & 1 & Tuğçe & 10 & $\begin{array}{l}\text { İrem, Gülden, Rıfat, } \\
\text { Tuğçe, Cenk, Fatih, } \\
\text { Irmak, Nehir, Seher, } \\
\text { Mert }\end{array}$ \\
\hline Kimya alan bilgisi & 12 & $\begin{array}{l}\text { Zeynep, İrem, } \\
\text { Rıfat, Fatih, } \\
\text { Tuğçe, Seher, } \\
\text { Nehir, Yağız, } \\
\text { Ayla, Gülden, } \\
\text { Cenk, Mert }\end{array}$ & 11 & $\begin{array}{l}\text { Irmak, Mert, } \\
\text { Nehir, Cenk, } \\
\text { Rıfat, Gülden, } \\
\text { Tuğçe, Fatih, } \\
\text { Yağı, Ayla, } \\
\text { İrem }\end{array}$ & 12 & $\begin{array}{l}\text { Nehir, Mert, } \\
\text { Zeynep, Tuğçe, } \\
\text { İrem, Ayla, } \\
\text { Yağı, Gülden, } \\
\text { Seher, Rıfat, } \\
\text { Irmak, Fatih }\end{array}$ & 10 & $\begin{array}{l}\text { Mert, Zeynep, İrem, } \\
\text { Gülden, Rifat, Ayla, } \\
\text { Fatih, Irmak, Yağı, } \\
\text { Seher }\end{array}$ \\
\hline Kalıcı öğrenme & 3 & $\begin{array}{l}\text { Fatih, Irmak, } \\
\text { Ayla }\end{array}$ & 4 & $\begin{array}{l}\text { Irmak, Gülden, } \\
\text { Fatih, Ayla }\end{array}$ & 1 & Irmak & 4 & $\begin{array}{l}\text { Cenk, Ayla, Fatih, } \\
\text { Irmak }\end{array}$ \\
\hline $\begin{array}{l}\text { Kimya konularını } \\
\text { gündelik hayat ile } \\
\text { ilişkilendirme }\end{array}$ & 4 & $\begin{array}{l}\text { Rifat, Fatih, } \\
\text { Irmak, Gülden }\end{array}$ & 6 & $\begin{array}{l}\text { Irmak, Rıfat, } \\
\text { Gülden, Fatih, } \\
\text { Seher, Ayla }\end{array}$ & 1 & Fatih & 6 & $\begin{array}{l}\text { Gülden, Tuğçe, } \\
\text { Ayla, Fatih, Irmak, } \\
\text { Seher }\end{array}$ \\
\hline
\end{tabular}

\begin{tabular}{llllllll}
\hline $\begin{array}{l}\text { Sorgulayıcı- } \\
\text { araştırma } \\
\text { yaklaşımı }\end{array}$ & 3 & $\begin{array}{l}\text { İem, Gülden, } \\
\text { Cenk }\end{array}$ & 6 & $\begin{array}{l}\text { Nehir, Cenk, } \\
\text { Rifat, Tuğçe, } \\
\text { Ayla, Irem }\end{array}$ & $\begin{array}{l}\text { Tuğçe, Yağı,, } \\
\text { Gülden, Seher, } \\
\text { Rifat, Irmak }\end{array}$ & Fatih \\
\hline Düşünme becerisi & 5 & $\begin{array}{l}\text { Rifat, Nehir, } \\
\text { Mert, Ayla, } \\
\text { Cenk }\end{array}$ & 2 & Yağı̆, Seher & & 2 & Cenk, Nehir \\
\hline
\end{tabular}

\begin{tabular}{llllll}
\hline $\begin{array}{l}\text { Bilgiyi ürüne } \\
\text { (tasarıma) } \\
\text { dönüştürülebilme }\end{array}$ & $\begin{array}{l}\text { Zeynep, İrem, } \\
\text { Rifat, Irmak, } \\
\text { Yağız }\end{array}$ & $\begin{array}{l}\text { Irmak, Tuğçe, } \\
\text { Seher }\end{array}$ & 1 & Seher \\
& & & & \\
\end{tabular}

\begin{tabular}{|c|c|c|c|c|c|c|c|}
\hline Grup çalışması & 1 Tuğçe & 1 & Tuğçe & 1 & Tuğçe & & \\
\hline Problem çözme & & 1 & Irmak & & & 1 & Cenk \\
\hline $\begin{array}{l}\text { Günlük hayattan } \\
\text { malzemeler ile } \\
\text { ürün } \\
\text { tasarlayabilme/ } \\
\text { çözüm üretebilme }\end{array}$ & $1 \quad$ Gülden & 9 & $\begin{array}{l}\text { Irmak, Mert, } \\
\text { Nehir, Cenk, } \\
\text { Rifat, Gülden, } \\
\text { Fatih, Yağız, } \\
\text { İrem }\end{array}$ & 1 & Mert & 1 & Mert \\
\hline Yaratıcilık & & & & & & 1 & Cenk \\
\hline
\end{tabular}

* Bir katılımcı etkinliğe katılmamıştır. 
Tablo 3 incelendiğinde öğretmen adaylarının tamamına yakını bütün FeTeMM eğitimi etkinliklerinin kendilerine alan bilgisi konusunda katkı sağladığını belirtmişlerdir. Bu kategoride öğretmen adayları yeni bilgiler öğrendiklerinden, eski bilgilerini tekrarlama firsatı bulduklarından ve öğrenmelerini pekiştirdiklerinden bahsetmişlerdir. Öğretmen adaylarının FeTeMM eğitimi etkinliklerinin alan bilgilerine katkı sağladığına ilişkin ifadelerine yönelik örnekler şöyledir:

"Kimya konularını tekrar etmemize ve bilmediğimiz bilgileri öğrenmeye sevk etti." (Yağız, Soğuk Kompres Torbası Tasarımı)

“... sadece bilgiyi bilmek yerine o bilgiyi kullanarak hem bilgili hem de kalıcı öğrenme gerçekleştirdik.” (Fatih, Soğuk Kompres Torbası Tasarımı)

“Bu etkinlikler kimya kavramını öğrenmemizde ve en önemlisi öğrendiğimizi uygulamamız açısından çok etkili ve kalıcı oluyor. Bu etkinlikte biyolojide ve kimyada canlılar ile bitkiler arasındaki solunum ve fotosentez reaksiyonlarını ögrenerek akvaryum içindeki $\mathrm{CO}_{2}$ miktarını nasıl tespit edeceğimizi öğrendik. Kısaca; denge, solunum ve fotosentez reaksiyonları, asit-baz kavramları ve indikatörün ne olduğunu ve nasıl seçileceğini öğrendik." (Irmak, Akvaryumdaki $\mathrm{CO}_{2}$ Ölçümü)

"Katalizörü, elmanın kararma reaksiyonunu, çarpışma teorisini, fiziksel ve kimyasal değişimler, radikal kavramı, şelat kavramını hatırlamam açısından bilgi sahibi olmayı kazandırdı.” (Zeynep, Elmanın Kararmasının Önlenmesi)

Alan bilgisi dışında, öğretmen adayları FeTeMM eğitimi etkinliklerinin kendilerine disiplinler arası bakış açısı, sorgulayıcı yaklaşım ve kimya konularını gündelik hayat ile ilişkilendirme hususunda katkı sağladıklarını belirtmişlerdir. Öğretmen adaylarının birçoğu özellikle "Soğuk Kompres Torbası Tasarımı” (n=10) ve "Elmanın Kararmasının Önlenmesi” $(\mathrm{n}=10)$ etkinliklerinin farklı disiplinleri birada kullanabilme ve ilişkilendirebilme konusunda kendilerine yarar sağladığını söylemişlerdir. Öğretmen adaylarının FeTeMM eğitimi etkinliklerinin disiplinler arası bakış açısı kazandırdığına ilişkin ifadelerine yönelik örnekler şöyledir:

“Farklı dersleri bir arada kullanabilme özelliği kazandırdı” (Seher, İndikatör Yapımı) 
"FeTeMM eğitimi uygulamasında sadece kimya bilgileri değil birçok alana (Fizik, Matematik, Fen, vb.) yönelmemizi sağladı.” (Tuğçe, Soğuk Kompres Torbası Tasarımı)

"Biyoloji, polimer kimyası, mühendislik alanında bilgi sahibi oldum aslında bilimin tüm dallarla iç içe olduğunu bütün alanların birbirinden etkilendiğini iyice kavrayıp görmüş oldum.” (Seher, Elmanı kararmasının önlenmesi)

"Kimya, biyoloji ve mühendislik alanlarını birbiri ile ilişkilendirmeyi öğrendim.” (Fatih, Elmanın Kararmasının Önlenmesi)

Elde edilen bulgulardan birisi de FeTeMM eğitimi etkinliklerinin öğretmen adaylarına sorgulayıcı-araştırma yaklaşımı kazandırdığı yönündedir. Bu sonuca dair örnekler ifadeler şöyledir:

"Araştırma, sorgulama, değerlendirme gibi özelliği bize kazandırdı ve tasarım yapmada hangi bilgiyi ya da malzemeyi nasıl kullanacağımız hakkında bilgi sahibi olduk." (Ayla, İndikatör Yapımı)

"FeTeMM eğitimi uygulaması araştırmaya, sorgulamaya, fikir edinmeye teşvik etti."(Gülden, Soğuk Kompres Torbası Tasarımı)

"Bu etkinlikte bilimi en başta sorgulayarak öğrendim. Öncelikle $\mathrm{CO}_{2}$ gazının miktarını ölçmek için neyi bilmem gerektiğini sorguladım ve $\mathrm{CO}_{2}$ 'nin kimyasal özelliklerini araştırdım. .... Daha sonra asit ve bazlarla ilgili bilgilerimi kullandım ve $\mathrm{CO}_{2}$ 'in varlığını bilmemiz için indikatör kullanmam gerektiğini düşündüm. Hangi indikatörü kullanmam gerektiğini de akvaryumun $\mathrm{pH}$ seviyesini öğrenip belirledim.” (Irmak, Akvaryumdaki $\mathrm{CO}_{2}$ Ölçümü)

"Daha çok araştırma ve bilgi edinmeye sürükledi." (Fatih, Elmanın Kararmasının Önlenmesi)

Öğretmen adaylarının yarısına yakını özellikle “Soğuk Kompres Torbası Tasarımı” (n=4), “İndikatör Yapımı” (n=6) ve "Elmanın Kararmasının Önlemesi” (n=6) etkinlikleri sayesinde kimya konularını günlük hayatla ilişkilendirebildiklerini belirtmişlerdir. $\mathrm{Bu}$ duruma yönelik örnek ifadeler şöyledir:

"FeTeMM eğitimi etkinliği kimya bilgilerimizi günlük hayata uyarlamamızı sağladı. Gittiğimiz bir okulda deney yapmak için malzeme bulamadığımızda günlük hayattan nasıl malzeme yapabileceğimizi öğrenmiş oldum.” (Irmak, İndikatör Yapımı) 
"Kimyada kullandığımız bazı malzemeleri, sadece laboratuvarda kullanmak dişında gündelik hayatta da kullanabileceğimizi öğrendik. Bu etkinlik ile kimya konularını gündelik hayat ile ilişkilendirdik ve kalıcı bilgiye sahip olduk." (Fatih, Soğuk Kompres Torbası Tasarım1)

"Bu etkinlik sayesinde günlük hayatta olan bir olayın aslında ne kadar da kimya ile ilgili olduğunun farkına vardım.” (Gülden, Elmanın Kararmasının Önlenmesi)

Öğretmen adayları (n=9) özelikle “İndikatör Yapımı” etkinliği sayesinde günlük hayattan malzemeler ile ürün tasarlanabileceği veya problemlere çözüm üretebileceği düşüncesine sahip olduklarını belirtmişlerdir. Bununla ilgili bir öğretmen adayının görüşü şöyledir:

"Bu etkinlikte, ileride öğretmen olarak gittiğim bir yerde deneyleri yapmama hiçbir şeyin engel olamayacağını öğrendim. Bir $\mathrm{pH}$ etkinliğinde illaki bir hazır indikatöre gerek olmayacağını, bu indikatörü günlük hayatta, her yerde bulunabilen meyvelerden kendimin hazırlayabileceğini öğrendim.” (Fatih, İndikatör Yapımı)

Yukarıda belirtilenlerin dışında, öğretmen adayları uygulanan FeTeMM eğitimi

etkinliklerinin düşünme becerilerini geliştirdiklerini daha çok uygulanan "Soğuk Kompres Torbası Tasarımı” etkinliği” aracılığgyla belirtmişlerdir. Bununla ilgili örnek ifade şöyledir:

"FeTeMM eğitimi etkinliği sayesinde mantıklı düşünme becerimin geliştiğini düşünüyorum.” (Rıfat, Soğuk Kompres Torbası Tasarımı)

Ayrıca az sayıda olmakla birlikte öğretmen adayları etkinliklerin grup olarak çalışma becerileri $(n=1)$, problem çözme becerileri $(n=2)$ ve yaratıcılık $(n=1)$ konularında da katk1 sağladığından bahsetmişlerdir.

\section{Öğretmen Adaylarının FeTeMM Eğitimi Etkinliklerinin En Öğretici Kısmına İlişkin}

\section{Görüşlerine Yönelik Bulgular}

Öğretmen adaylarının sürecin öğretici kısımlarına yönelik görüşlerine bütünsel bir bakış sağlamak amacıyla Tablo 4'de etkinlikler ve ilgili etkinliklere dair öğretmen adaylarının öğretici bulduğu kısımlar gösterilmiştir. 
Tablo 4

FeTeMM Ĕ̆gitimi Etkinliklerinin En Öğretici Kısmına İlişkin Bulgular

\begin{tabular}{|c|c|c|c|c|c|c|c|c|c|}
\hline \multirow[t]{2}{*}{ Tema } & \multirow[t]{2}{*}{ Kategori } & \multicolumn{2}{|c|}{$\begin{array}{l}\text { Soğuk Kompres } \\
\text { Torbası Tasarımı }\end{array}$} & \multicolumn{2}{|c|}{$\begin{array}{l}\text { Índikatör } \\
\text { Yapımı* }\end{array}$} & \multicolumn{2}{|c|}{$\begin{array}{l}\text { Akvaryumdaki } \\
\mathrm{CO}_{2} \text { ölçümü* }\end{array}$} & \multicolumn{2}{|c|}{$\begin{array}{l}\text { Elmanın } \\
\text { Kararmasının } \\
\text { Önlenmesi }\end{array}$} \\
\hline & & $\mathbf{f}$ & Katılımcılar & $\mathbf{f}$ & Katılımcılar & f & Katılımcilar & f & Katılımcilar \\
\hline \multirow[t]{3}{*}{$\begin{array}{l}\text { Etkinlik } \\
\text { uygulama } \\
\text { aşamaları }\end{array}$} & $\begin{array}{l}\text { Tasarım } \\
\text { yapma (ürün } \\
\text { ortaya koyma) }\end{array}$ & 7 & $\begin{array}{l}\text { Cenk, Irmak, } \\
\text { Fatih, Rıfat, } \\
\text { Yağı, Nehir, } \\
\text { Gülden }\end{array}$ & 2 & Ayla, Irmak & 3 & $\begin{array}{l}\text { Nehir, Fatih, } \\
\text { Irmak }\end{array}$ & 1 & Mert \\
\hline & Araştırma & 3 & $\begin{array}{l}\text { Ayla, Tuğçe, } \\
\text { İrem }\end{array}$ & 8 & $\begin{array}{l}\text { Yağız, Fatih, } \\
\text { Gülden, } \\
\text { Rifat, Cenk, } \\
\text { Nehir, Mert, } \\
\text { İrem }\end{array}$ & 7 & $\begin{array}{l}\text { Tuğçe, } \\
\text { Zeynep, } \\
\text { İrem, Ayla, } \\
\text { Yağız, } \\
\text { Gülden, } \\
\text { Rifat }\end{array}$ & 7 & $\begin{array}{l}\text { Yağı, Irmak, } \\
\text { Fatih, Ayla, } \\
\text { Gülden, İrem, } \\
\text { Zeynep }\end{array}$ \\
\hline & $\begin{array}{l}\text { Ürünleri } \\
\text { sunulması ve } \\
\text { değerlendirme }\end{array}$ & 2 & Mert, Seher & 1 & Seher & 2 & Mert, Seher & 3 & $\begin{array}{l}\text { Nehir, Rifat, } \\
\text { Seher }\end{array}$ \\
\hline \multirow{2}{*}{$\begin{array}{l}\text { Genel } \\
\text { özellikler }\end{array}$} & Grup çalışması & 1 & Zeynep & 1 & Tuğçe & & & & \\
\hline & $\begin{array}{l}\text { Disiplinler } \\
\text { arası bakış } \\
\text { açısı }\end{array}$ & & & & & & & 2 & Cenk, Tuğçe \\
\hline
\end{tabular}

* Bir katılımcı etkinliğe katılmamıştır.

Tablo 4 incelendiğinde öğretmen adaylarının etkinliklerin öğreticiliğini değerlendirirken çoğunlukla etkinliğin uygulama aşamalarını dikkate aldıkları bazı öğretmen adaylarının ise etkinliklerin genel özelliklerini dikkate aldıkları görülmektedir. Öğretmen adayları uygulama aşamaları arasından en çok araştırma yapma kısmının öğretici olduğunu belirtmişlerdir. Bu duruma yönelik örnek ifadeler şöyledir:

"En öğretici kısım araştırma kısmıydı. Çünkü bu kısımda daha önce bilmediğimiz kısımları öğrendik. Bilgileri kendimiz araştırdığımız için daha kalıcı bilgiler edindik.” (Fatih, İndikatör Yapımı)

"Bu uygulamada en öğretici kısım araştırma kısmıydı. Çünkü materyali tasarlamak için önce bilgi sahibi olmalıyız, araştırmalıyız, sorgulamalıyız. Bu aşamalar bizim öğrenmemize neden oluyor." (Zeynep, Akvaryumdaki $\mathrm{CO}_{2}$ Ölçümü)

"Bu etkinlikte en öğretici kısım kararma olayını öncelikle kendi imkanlarımızla araştırıp bulmak oldu. Bu bize ön bilgi sağladı.” (Gülden, Elmanın Kararmasının Önlenmesi) 
İkinci olarak tasarım yapma kısmı ve üçüncü olarak tasarlanan ürünlerin test edilmesi ve değerlendirilmesi aşamaları öğretmen adayları tarafından en öğretici kısım olarak değerlendirilmiştir. Bu duruma yönelik örnek ifadeler şöyledir:

"Benim için en öğretici kısım kendi alan bilgimizi kullanarak hayatımızı kolaylaştırmak için bir ürün elde etmekti. Bu ürünü oluşturmak için kullandığımız alan bilgisinin yeterli olup olmadığının farkına varmış oldum.” (Rıfat, Soğuk Kompres Torbası Tasarımı)

"En öğretici kısım kendi indikatörümüzü kendimiz tasarlamamızdı. Çünkü indikatörü yaparken asit ve bazları ve indikatörün asit ve bazlarda nasıl çalıştığını öğrendik.” (Irmak, İndikatör Yapımı)

"Burada en öğretici kısım kullanacağımız indikatörün akvaryuma nasıl yerleştireceğimizi bulma kısmıydı. Çünkü burada bütün bilgilerimizi kullandık." (Fatih, Akvaryumdaki $\mathrm{CO}_{2}$ Ölçünü)

"Her grubun farklı çalışmalarını gördük, nerde ne yanlış yaptığımızı, eksiklerimizi değerlendirme firsatı verdi.” (Mert, Soğuk Kompres Torbası Tasarımı)

"Bence bütün grupların tasarımı sunup uyguladığı zaman çünkü gözle görülür bir şekilde neyin ne olduğunu anlayıp test edebiliyorduk. Ayrıca herkes kendi düşüncesini ve nedeni de anlatıyordu. Böylece eksik ve doğru yönleri tam anlamıyla gözlemleyebiliyorduk." (Seher, İndikatör Yapımı)

"Etkinliği uygularken yöntemimiz etkili oldu mu? Etkili olmadıysa neden? Gibi sorulara cevap verme aşaması en öğretici kısımdır. Çünkü olayı daha derin araştırmamıza ve daha çok bilgi edinmemizi sağlıyor.” (Nehir, Elmanın Kararmasının Önlenmesi)

Az sayıda olmasına rağmen bazı öğretmen adayları grup çalışması $(n=2)$ veya disiplinler arası bakış açısının kullanılması $(\mathrm{n}=2)$ gibi etkinliklerin genel özelliklerini dikkate alarak bu kısımları en öğretici kısımlar olarak değerlendirmişlerdir. Bunlarla ilgili örnek ifadeler şöyledir:

"Araştırma ve düşünme kısmıydı. Biz grup arkadaşlarımızla bilgilerimizi birbirimize nedenleriyle açıklıyorduk. Birbirimizle yaptığımız grup tartışması ile ister istemez birbirimizden bir şeyler öğreniyorduk.” (Zeynep, Soğuk Kompres Torbası Tasarımı)

"En öğretici kısım birçok alanın bir arada kullanılması (biyoloji, mühendislik, kimya, vb.) ve grup halinde çalışarak bir sonuca ulaşmak (Tuğçe, Elmanın Kararmasının Önlenmesi) 


\section{Öğretmen Adaylarının FeTeMM Eğitimi Etkinliklerine Dair Uygulamaların En Zor Kısmına}

\section{İlişkin Görüşlerine Yönelik Bulgular}

Öğretmen adaylarının sürecin zor kısımlarına yönelik görüşlerine bütünsel bir bakış sağlamak amacıyla Tablo 5'de etkinlikler ve ilgili etkinliklere dair öğretmen adaylarının en zor bulduğu kısımlar gösterilmiştir.

Tablo 5

FeTeMM Ĕ̈itimi Etkinliklerinin En Zor Kısmına İlişkin Bulgular

\begin{tabular}{|c|c|c|c|c|c|c|c|c|c|c|}
\hline \multirow[t]{2}{*}{ Tema } & \multirow[t]{2}{*}{ Kategori } & \multirow[t]{2}{*}{ Alt Kategori } & \multicolumn{2}{|c|}{$\begin{array}{l}\text { Soğuk Kompres } \\
\text { Torbası Tasarımı }\end{array}$} & \multicolumn{2}{|c|}{$\begin{array}{l}\text { Indikatör } \\
\text { Yapımı* }\end{array}$} & \multicolumn{2}{|c|}{$\begin{array}{l}\text { Akvaryumdaki } \\
\mathrm{CO}_{2} \text { ölçümü* }\end{array}$} & \multicolumn{2}{|c|}{$\begin{array}{l}\text { Elmanın } \\
\text { Kararmasının } \\
\text { Önlenmesi }\end{array}$} \\
\hline & & & $\mathbf{f}$ & Katılımcilar & $\mathbf{f}$ & Katılımcılar & f & Katılımcılar & $\mathbf{f}$ & Katılımcılar \\
\hline \multirow[t]{4}{*}{$\begin{array}{l}\text { Etkinlik } \\
\text { uygulama } \\
\text { aşamaları }\end{array}$} & Tasarım & $\begin{array}{l}\text { Ürünün } \\
\text { tasarımına } \\
\text { karar verme }\end{array}$ & 10 & $\begin{array}{l}\text { Mert, Nehir, } \\
\text { Cenk, } \\
\text { Gülden, Ayla, } \\
\text { Zeynep, } \\
\text { Yağı, Rıfat, } \\
\text { Fatih, Seher }\end{array}$ & & & 7 & $\begin{array}{l}\text { Nehir, Rıfat, } \\
\text { Gülden, } \\
\text { Zeynep, } \\
\text { Irmak, Yağız, } \\
\text { Ayla }\end{array}$ & 5 & $\begin{array}{l}\text { Rifat, } \\
\text { Gülden, } \\
\text { Cenk, Seher, } \\
\text { Ayla }\end{array}$ \\
\hline & & $\begin{array}{l}\text { Kullanılacak } \\
\text { malzemelere } \\
\text { karar verme }\end{array}$ & 1 & İrem & 9 & $\begin{array}{l}\text { Tuğçe, Rifat, } \\
\text { Cenk, Nehir, } \\
\text { Mert, Irmak, } \\
\text { İrem, Seher, } \\
\text { Ayla }\end{array}$ & 1 & Tuğçe & 1 & Irmak, \\
\hline & Yapma & $\begin{array}{l}\text { Tasarımı } \\
\text { uygulamaya } \\
\text { dökmek } \\
\end{array}$ & & & 1 & Gülden & & İrem, Seher & & \\
\hline & Araştırma & $\begin{array}{l}\text { Gerekli } \\
\text { bilgiyi } \\
\text { edinmek } \\
\end{array}$ & & & 2 & Fatih, Yağız & & Fatih, Mert & 6 & $\begin{array}{l}\text { Mert, Tuğçe, } \\
\text { İrem, Zeynep, } \\
\text { Yağız, Nehir }\end{array}$ \\
\hline $\begin{array}{l}\text { Genel } \\
\text { özellikler }\end{array}$ & \multicolumn{2}{|c|}{$\begin{array}{l}\text { Disiplinler arası ilişki } \\
\text { kurmak }\end{array}$} & 2 & Tuğçe, Irmak & & & & & & Fatih \\
\hline
\end{tabular}

Tablo 5 incelendiğinde öğretmen adayları etkinlikler sırasında en zorlandıkları kısımları değerlendirirken çoğunlukla etkinliğin uygulama aşamalarını dikkate alırken bazı öğretmen adaylarının etkinliklerin genel özelliklerini dikkate aldıkları görülmektedir. Öğretmen adayları uygulama aşamaları arasından en çok tasarım yapma (ürün ortaya koyma) ve araştırma yapma kısımlarında zorluk çektiklerini belirtmişlerdir. Öğretmen adayları tasarım yapma aşamasında en 
çok tasarımın nasıl olacağına ve hangi malzemeleri kullanacaklarına karar verirken zorluk yaşadıklarını söylemişlerdir. Bu duruma yönelik örnek ifadeler şöyledir:

"Bir tasarım elde edeceğiz ama birçok etmeni kapsaması lazım veya tasarım için hangi malzemeleri neden kullanacağımızı, tasarımımıza hangi maddelerin uygun olacağını ve tasarım şeklimizin nasıl olacağı kısmı en zor kısımdı.” (Zeynep, Soğuk Kompres Torbası Tasarımı)

"FeTeMM eğitimi uygulamasında en zor kısım tasarım kısmıydı. Çünkü akvaryum ve indikatörün bir bağlantısı olması gerekiyordu, indikatörün suya karışmaması ve suyun içindeki $\mathrm{CO}_{2}$ gazının indikatöre gitmesi gerekiyordu. $\mathrm{Bu}$ yüzden düzenek hazırlarken burada çok zorlandım.” (Irmak, Akvaryumdaki CO2 Ölçümü)

"En zor kısım korumayı önlemek için neler yapmam gerekiyor nasıl bir madde kullansam engellerim diye bu konuda zorlandım.” (Cenk, Elmanın Kararmasının Önlenmesi)

"Yaptığımız araştırma sonucu birçok sebze, meyve ve bitkiden indikatör elde edebiliyorduk. Bu güzel bir bilgiydi. Fakat bu indikatörlerden bir tanesinde karar kılma aşaması zordu." (Irmak, İndikatör Yapımı)

İkinci olarak etkinliğin araştırma kısmında yaşadıkları zorluklara ilişkin öğretmen adayların görüşleri ise şu şekildedir.

"Burada en zor kısım araştırma kısmıydı. Çünkü bu etkinlikte Türkçe kaynaklar bulmak oldukça zordu. İndikatörlerin hazırlanması kısmı da zordu çünkü kaynak eksikliği vardı." (Fatih, İndikatör Yapımı)

"Bu FeTeMM eğitimi uygulamasında en zor kısım sudaki $\mathrm{CO}_{2}$ miktarını nasıl ölçeceğimize dair bilgiyi edinmek oldu çünkü hiçbir fikrimiz yoktu.” (Mert, Akvaryumdaki $\mathrm{CO}_{2}$ Ölçümü)

"En zor kısım elmadaki kararmanın nedenini öğrenmek, kararmayı önlemek için ne yapılması gerektiğini bulmak oldu." (Yağız, Elmanın Kararmasının Önlenmesi)

Tasarım ve araştırma aşamalarının dışında öğretmen adaylarının $(n=3)$ birkaçı da tasarımın uygulamaya dökülüp yapılma aşamasında zorluk çektiklerini belirtmişlerdir. Buna dair bir öğretmen adayının ifadesi şu şekildedir:

"Beni en çok zorlayan kısım bulduğumuz bilgileri pratiğe dökme kısmıydı. Tasarımı kağıt üstünde yaptık fakat malzemeleri birleştirirken aksaklıklar [oldu] ve düşündüğümüz gibi olmadı bazı kısımlar. Bu da yeniden tasarımı gözden geçirmemize neden oldu." (Seher, Akvaryumdaki $\mathrm{CO}_{2}$ Ölçümü) 
Öğretmen adaylarının bazıları ( $\mathrm{n}=3)$ ise etkinliklerin genel bir özelliği olan disiplinler arası ilişki kurmakta çok zorluk yaşadıklarını belirtmişlerdir. Buna dair bir öğretmen adayının ifadesi şu şekildedir:

"Bu etkinlikte kimyayı biyoloji ile ilişkilendirmek zordu. Her zaman sadece olaya kimya gözüyle baktı̆̆ımız için diğer alanlar ile ilişkilendirmek zor oluyor.” (Fatih, Elmanın Kararmasının Önlenmesi)

\section{Tartışma}

$\mathrm{Bu}$ çalı̧̧mada altı hafta boyunca FeTeMM eğitimi etkinliklerine katılan kimya öğretmen adaylarından uygulanan etkinlikleri ve deneyimlerini temel alarak FeTeMM uygulamalarını değerlendirmeleri istenmiştir. Elde edilen bulgular FeTeMM eğitimi etkinliklerinin öncelikle öğretmen adaylarının yeni bilgiler öğrenmelerine, eski bilgilerini hatırlamalarına ve pekiştirmelerine yardımcı olarak öğrenmeyi kalıcı hale getirdiğini ortaya koymuştur. Bu sonuçlar FeTeMM eğitimi etkinliklerinin katılımcıların kimya alan bilgisine yardımcı olabileceğini göstermektedir.

Alan bilgisinden sonra etkinliklerin en çok öğretmen adaylarının disiplinler arası bakış açısı kazanmalarına, kimya konularını gündelik hayat ile ilişkilendirebilmelerine ve karşılaştıkları problemleri sorgulayıcı yaklaşımla ele almalarına olumlu katkılar sağladığı görülmüştür. $\mathrm{Bu}$ çalışmada FeTeMM eğitimi etkinliklerinin katılımcılara disiplinler arası bakış açısı kazandırma konusundaki olumlu katkılarına ilişkin sonuçlar alan yazındaki diğer sonuçlar ile paralellik göstermektedir. Ortiz, Bos ve Smith (2015) öğretmen adayı ve öğretmelerle yaptıkları çalışmada $(\mathrm{n}=25)$ katılımcıların verilen modül sonunda bu tür uygulamaların disiplinler arası bakış açısını geliştirdiğini belirtmişlerdir. Aslan-Tutak, Akaygün ve Tezsezen (2017) ve Gökbayrak ve Karışan (2017a) çalışmalarında FeTeMM eğitimi sonunda öğretmen adaylarının alanlar arası ilişkiyi bütünleşik olarak görebildikleri sonucuna ulaşmıştır. Benzer şekilde, Eroğlu ve Bektaş (2016) da 
çalışmalarının sonucunda FeTeMM eğitimi almış fen bilimleri öğretmenlerinin fen derslerini farklı alanlarla iliş̧kilendikleri ve fen dersini disiplinler arası bir yaklaşımla ele aldıklarını belirtmiştir. Öğretmen adaylarının FeTeMM eğitimi etkinliklerini kimya ve günlük yaşam arasındaki ilişkiyi kurmalarına ve anlamalarına yardımcı olduğu yönündeki değerlendirmeleri FeTeMM eğitimi etkinliklerinin gerçek hayatla ilgili sorunların çözümü konusunda katılımcıların hazır bulunuşluklarını artırmada katkı sağlayacağını göstermektedir (Gökbayrak ve Karışan, 2017a). Ayrıca FeTeMM eğitimi etkinlikleri, öğrencileri farklı disiplinleri bütünleştirerek araştırma, tasarım, problem çözme ve takım çalışması becerilerine odaklanmalarına sağlayarak gerçek hayat sorunlarına çözüm üretmelerine firsat tanınmasından dolayı günlük sorunlarını çözebilen ve toplumun ihtiyaçlarına katkıda bulunabilen ve 21. Yüzyıla ayak uydurabilen bireylerin yetiştirilmesine katk1 sağlayacağı düşünülmektedir.

Bu çalışmanın sonuçları dikkate alındığında etkinliklerin öğretmen adaylarını sorgulayarak ve araştırarak öğrenmelerine teşvik etmesi nedeniyle FeTeMM eğitimi etkinliklerinin katılımcılara fen eğitiminin temel prensiplerini kazandırabileceğini göstermektedir. Benzer olarak, Murphy ve Mancini-Samuelson (2012) vermiş oldukları FeTeMM sertifika eğitimi sonunda, katılımcıların bilimsel konuları tartışma, bilimsel kanıtları kullanarak argüman oluşturma ve medyada sunulan bilimsel haberler hakkında kritik düşünme noktalarında kendilerine olan güvenlerinin arttı̆̆ını belirtmişlerdir.

$\mathrm{Bu}$ çalışmada FeTeMM eğitimi etkinliklerinin öğretmen adaylarına internet kullanarak araştırma yapma olanağı sunması ve bir ürün ortaya çıkarmalarını istemesi öğretmen adayları tarafindan sürecin en öğretici aşamaları olarak değerlendirildiği sonucuna ulaşılmıştır. Bunun yanı sıra ortaya konulan ürünlerin sunulması ve değerlendirmesi aşaması da kendi eksikliklerini görmeleri ve başka fikirleri görmelerini sağladığı için öğretici nitelik taşıdığı belirlenmiştir. Bu 
çalışmayla benzer şekilde, Bozkurt-Altan, Yamak ve Buluş-Kırıkkaya (2016) tarafından yapılan çalışma da bu süreçlerin öğretmen adayları tarafından tasarım temelli fen eğitiminin olumlu yönleri olarak değerlendirildiği ortaya konulmuştur.

Öğretmen adaylarının FeTeMM eğitimi etkinliklerinin uygulama sürecinin aşamalarına ilişkin değerlendirmelerinde en çok tasarımı gerçekleştirme süreci içerisinde ürünü nasıl tasarlayacakları ve hangi malzemeleri kullanacaklarını karar verme aşamalarında zorluk yaşadıkları belirlenmiştir. Benzer şekilde, Bozkurt-Altan, Yamak ve Buluş-Kırıkkaya (2016)'da en çok problemlere dair çözümlerin geliştirilmesi aşamasında zorluk çekildiğini ortaya koymuştur. Öğretmen adaylarının eğitim hayatlarında öğrenci merkezli, probleme ve sorgulamaya dayalı aktif öğrenme etkinliklerine dair deneyim yaşamadıkları ya da deneyimleri yetersiz olduğu için sürecin bu aşamasını en zor olarak değerlendirdikleri düşünülebilir. Ayrıca bu çalışmada tasarım öncesi gerekli bilgiyi edinmek için başvurulan araştırma aşamasında Türkçe kaynak eksikliği ve zamanın kısıtlı olmasından dolayı öğretmen adaylarının zorluk yaşadıkları belirlenmiştir.

\section{Öneriler}

Günümüzde ABD başta olmak üzere farklı ülkelerde kullanılan FeTeMM eğitimi yaklaşımı ilköğretim programlarına girmiş bulunmaktadır. Çağın gereksinimi olan bilgi ve becerileri öğrencilerimize kazandırmak için okullarımızda FeTeMM yaklaşımının uygulanabilmesi için önceliğin öğretmen eğitimine verilmesi, FeTeMM yaklaşımını anlamış, deneyimlemiş ve önemini kavramış öğretmenler yetiştirilmesi alan eğitimcileri olarak önceliğimiz olmalıdır. Bu ihtiyaçtan hareketle yola çıkmış olduğumuz araştırmanın bulguları 1şı̆̆ında FeTeMM yaklaşımı farklı bağlamlarda (Özel öğretim yöntemleri dersleri, seçmeli FeTeMM dersi vb. gibi) sunulmalıdır. Ayrıca, genel olarak zaman sıkıntısı problemini çözebilmek adına okul dışı öğrenme ortamlarında da bu tür etkinliklerin uygulanması hem katılımcıların not kaygılarını azaltacak hem de zaman 
kaygısı olmadan bir ürün tasarlamak ve bu süreçten yararlanarak öğrenme söz konusu olacaktır. Özellikle, öğretmen adaylarının da belirttiği üzere mevcut ya da araştırma aşamasında öğrenmiş olduğu bilgileri bir tasarımda kullanmaları katılımcılar için çok değerlidir. Bu noktada, öğretmen eğitimi programlarına temel düzeyde tasarım, yaratıcılık ve mühendislik seçmeli dersinin eklenmesi faydalı olacaktır. Daha önceki yaşantıları düşünüldüğünde katılımcılar elde edilen bilgileri ürün oluşturma ya da tasarım yapma amaçlı kullanmadıkları için zorlanmışlardır. $\mathrm{Bu}$ zorlanmaların belirtilen derslerin sunulması ile aşılabileceği düşünülmektedir. Yine öğretmen eğitimi ile ilgili olarak öğretmenlerin disiplinler arası yaklaşım ile öğretim yapmasının önündeki en önemli engellerden biri bu tür bir eğitim için gerekli alan bilgisine sahip olmamalarıdır (Stinson vd., 2009). Bu eksikliğin giderilmesi için disiplinler arası bağlantıların hem mevcut derslerde verilmesi hem de bu tür seçmeli derslerin açılması gelecekte öğretmen olacak adayların bu zayıflıklarının giderilmesine yardımcı olacaktır.

Açılmış olan ya da mevcut derslerin bünyesinde sunulan FeTeMM eğitimlerinde, özellikle araştırma noktasında katılımcıların öğrenmeleri bu basamağın yapılandırılabileceğini ortaya koymaktadır. Bu noktada, Wheeler vd. (2014) tarafindan ortaya konan ve yönlendirici sorular içeren (Bu etkinliği gerçekleştirebilmek için neleri bilmek istersiniz, Hangi materyaller soğuk kompres torbası tasarımı için ideal olabilir? Neden? Hangi kaynakları araştırmak tasarımınız için faydalı olabilir? vb.) bir yapılandırılmış tasarım seyir formu kullanımı ve grupların araştırmalarının izlenmesi araştırma basamağındaki öğrenmeyi daha kaliteli hale getirmesi açısından önemlidir.

İleride gerçekleştirilecek olan çalışmalarda, alan eğitimcileri bu tür derslerin öğretmen adaylarının alan bilgilerine etkisine odaklanmalıdırlar. Ayrıca, farklı FeTeMM eğitimi öğretmen yetiştirme modellerini farklı gruplara sunup hem öğretmen adayı hem de öğretmenlerin FeTeMM öğretimi gelişimleri takip edilmelidir. Bunlara ek olarak, farklı alanlardan (mühendislik, fen 
alanları ve teknoloji ile ilgili alanlardaki) öğretim üyelerinin birlikte sundukları derslerin hem öğretmen adaylarının hem de dersi birlikte hazırlayan öğretim üyelerinin FeTeMM öğretimine yönelik pedagojik alan bilgilerinin gelişiminin çalışılması alana önemli katkı yapacağı düşünülmektedir.

\section{Makalenin Bilimdeki Konumu (Yeri)}

Matematik ve Fen Bilimleri Eğitimi Bölümü/Kimya Eğitimi Anabilim Dalı

\section{Makalenin Bilimdeki Özgünlüğü}

Yeni bir yaklaşım olan FeTeMM eğitimi yaklaşımını bilen, kullanabilen ve yeni etkinlikler tasarlama noktasında bilgili ve deneyimli öğretmen yetiştirebilmek adına henüz göreve başlamamış ve eğitim almakta olan ögretmen adaylarını donatmak atılacak en önemli adımların başında gelmektedir. Öğretmen adaylarına sunulacak eğitimler sırasında öğretmen adaylarının FeTeMM eğitimi etkinliklerinin kendilerine sağladığı katkılar, etkinliklerin en öğretici kısmı ve en zor kısmı hakkında ortaya koyduğu noktalar daha sonra organize edilecek benzer eğitimlerin yapılandırılmasına da 1şık tutacaktır. Bu noktada gerçekleştirilen bu çalışma alan yazına ve öğretmen eğitimcilerine önemli bilgiler sunacaktır.

\section{Kaynakça}

Akgündüz, D., Aydeniz, M., Çakmakçı, G., Çavaş, B., Çorlu, M. S., Öner, T. ve Özdemir, S. (2015). STEM eğitimi Türkiye raporu: Günün modası mı yoksa gereksinim mi? [A report on STEM Education in Turkey: A provisional agenda or a necessity?][White Paper]. İstanbul, Turkey: Aydın Üniversitesi.

Aslan-Tutak, F., Akaygün, S. ve Tezsezen, S. (2017). İşbirlikli FeTeMM (Fen, Teknoloji, Mühendislik, Matematik) eğitimi uygulaması: Kimya ve matematik öğretmen adaylarının 
FeTeMM farkındalıklarının incelenmesi. Hacettepe Üniversitesi Eğitim Fakültesi Dergisi, 32(4), 794-816. DOI: 10.16986/HUJE.2017027115

Aydın-Günbatar, S., Tarkın-Çelikkıran, A., ve Demirdöğen, B. (2017). Kimya öğretiminde fen, teknoloji, mühendislik ve matematik (FeTeMM) uygulamaları. A. Ayas ve M. Sözbilir (Ed.) Kimya Öğretimi: Öğretmen Ĕgitimcileri, Öğretmenler ve Öğretmen Adayları İçin İyi Uygulama Örnekleri (469-490). Ankara: Pegem Akademi.

Bissaker, K. (2014). Transforming STEM education in an innovative Australian school: The role of teachers' and academics' professional partnership. Theory into Practice, 53, 55-63, DOI:10.1080/00405841.2014.862124.

Bozkurt-Altan, E., Yamak, H. ve Buluş-Kırıkkaya, E. (2016). FeTeMM eğitim yaklaşımının öğretmen eğitiminde uygulanmasına yönelik bir öneri: Tasarım temelli fen eğitimi. Trakya Üniversitesi Eğitim Fakültesi Dergisi, 6(2), 212-232.

Burrows, A. C., Breiner, J. M., Keiner, J. ve Behm, C. (2014). Biodiesel and integrated STEM: vertical alignment of high school biology/biochemistry and chemistry. Journal of Chemical Education, 91(9), 1379-1389.

Carmel, J. H., Ward, J. S. ve Cooper, M. M. (2017). A glowing recommendation: A Project-based cooperative laboratory activity to promote use of the scientific and engineering practices. Journal of Chemical Education. 94(5), 626-631. DOI: 10.1021/acs.jchemed.6b00628.

Cooper, M. M. (2013). Chemistry and the Next Generation Science Standarts. Journal of Chemical Education. 90, 679-680. DOI: 10.1021/ed400284c.

English, L. D. ve King, D. T. (2015). STEM learning through engineering design: Fourth-grade students' investigations in aerospace. International Journal of STEM Education, 2(1), 14. 
Eroğlu, S. ve Bektaş, O. (2016). STEM eğitimi almış fen bilimleri öğretmenlerinin STEM temelli ders etkinlikleri hakkındaki görüşleri. Eğitimde Nitel Araştırmalar Dergisi - Journal of Qualitative Research in Education, 4(3), 43-67. DOI: 10.14689/issn.2148-2624.1.4c3s3m

Gökbayrak, S. ve Karışan, D. (2017a, Ekim). Fen Bilgisi Öğretmen Adaylarının Stem Temelli Etkinlikler Hakkındaki Yansıtıcı Yazımlarının Incelenmesi. Sözel bildiri, 2. Uluslararası Eğitimde İyi Uygulamalar ve Yenilikler Konferansı, İzmir, Türkiye.

Gökbayrak, S. ve Karışan, D. (2017b, Ekim). Stem Etkinliklerinin Fen Bilgisi Öğretmen Adaylarının Bilimsel Süreç Becerilerine Etkisi. Sözel bildiri, 2. Uluslararası Eğitimde İyi Uygulamalar ve Yenilikler Konferansı, İzmir, Türkiye.

Kennedy, T. ve Odell, M. (2014). Engaging students in STEM education. Science Education International, 25(3), 246-258.

Marshall, C. ve Rossman, G. B. (2006). Designing qualitative research (4th Edition). USA: Sage Publications.

Milli Eğitim Bakanlığı (MEB) (2017). Fen Bilimleri Dersi Öğretim Programı (3, 4, 5, 6, 7 ve 8.

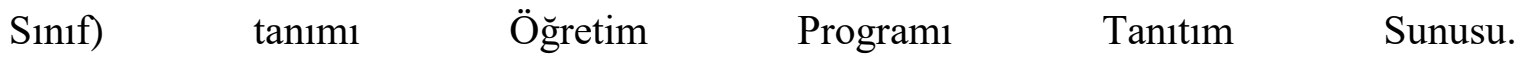
https://tegm.meb.gov.tr/meb_iys_dosyalar/2017_06/09163104_Fen_Bilimleri_Dersi_YYr etim_ProgramY_Karș1laștırmalar.pdf adresinden 8.10.2017 tarihinde indirilmiştir.

Merriam, S. B. (2013). Nitel Araştırma Desen ve Uygulama için Bir Rehber (Çev. Ed. S. Turan). Nobel Akademik Yayıncılık.

Murphy, T. P. ve Mancini-Samuelson, G. J. (2012). Graduating STEM competent and confident teachers: The creation of a STEM certificate for elementary education majors. Journal of College Science Teaching, 42(2), 18-23. 
National Association of Colleges and Employers (NACE). (2015). Job Outlook 2016: Attributes employers want to see on new college graduates' resumes. https://www.goodcall.com/news/nace-job-outlook-2016-what-employers-want-to-see-onyour-resume-03807 adresinden Şubat 2017 tarihinde ulaşılmıştır.

National Research Council (NRC). 2012. A framework for $K-12$ science education: Practices, crosscutting concepts, and core ideas. Washington, DC: National Academies Press.

Ortiz, A. M., Bos, B. ve Smith, S. (2015). The power of educational robotics as an integrated STEM learning experience in teacher preparation programs. Journal of College Science Teaching, 44(5), 42-47.

Sanders, M. (2009). STEM, STEM education, STEMmania. The Technology Teacher, 68(4), 2026.

Stinson, K., Harkness, S., Meyer, H. ve Stallworth, J. (2009). Mathematics and science integration: Models and characterizations. School Science and Mathematics, 109(3), 153161, DOI:10.1111/j.1949-8594.2009. tb17951.x

Stohlmann, M., Moore, T. ve Roehrig, G. H. (2012). Considerations for teaching integrated STEM education. Journal of Pre-college Engineering Education Research, 2(1), 28-34. DOI: $10.5703 / 1288284314653$.

Teo, T. W. ve Ke, K. J. (2014) Challenges in STEM teaching: Implication for preservice and inservice teacher education program. Theory into Practice, 53(1), 18-24. DOI:0.1080/00405841.2014.862116.

Tezel, Ö. ve Yaman, H. (2017). FeTeMM eğitimine yönelik Türkiye'de yapılan çalışmalardan bir derleme. Ĕ̌gitim ve Öğretim Araştırmaları Dergisi, 6(1), 135-145. 
Yıldırım, A. ve Şimşek, H. (2011). Sosyal Bilimlerde Nitel Araştırma Yöntemleri (8. Basım). Ankara: Seçkin Yayıncılık.

Wheeler, L., Whitworth, B. ve Gonczi, A. (2014). Engineering design challenge. The Science Teacher, 81(9), 30-36.

\section{Summary}

Problem Statement: We live in an industrialized world that requires effective use of science and technology. Such world demands a labor force that has the capability of identifying, adapting, and utilizing scientific and technological knowledge for developing unique technologies (Kennedy and Odell, 2014). Despite the growing need, the number of people who prefer science, technology, engineering and mathematics (STEM) as a profession in the universities in the United States, Europe and Australia has been decreasing day by day (National Research Council [NRC], 2012). Similar problems are also emerging in Turkey. Therefore, it has gained importance to raise individuals and employees equipped with STEM related knowledge and practices. One and the most agreed upon learning experience is an interdisciplinary approach that incorporates engineering design with the practical applications of science. With this in mind, this study aimed at pre-service chemistry teachers who will teach chemistry in the future. In order to educate experienced and knowledgeable teachers at the point of emphasizing teaching and applying different disciplines and areas together, this study provided a six-week training session on what STEM training is and how it should be done.

Purpose of the Study: The purpose of the present study is to investigate pre-service chemistry teachers' ideas about four activities prepared in light of Science, Technology, Engineering and Mathematics (STEM) integrated approach. 
Method(s): In this study, a case study research methodology was used. The sample of this study consisted of 13 pre-service chemistry teachers who enrolled in Teaching Method Course II. During the course, pre-service teachers participated four activities based on integrated STEM approach. In the application of the activities, design approach model suggested by Wheeler et al. (2014) was used. Data were collected through reflection papers after each activity by asking participants to write about the contribution of the activity, the most informative part of the activity, and the hardest part of the activity. The data were analyzed through content analysis, descriptive analysis, and constant-comparative method.

Findings and Discussions: The findings of the data analysis are summarized under three headings: (1) contribution of STEM activities to pre-service teachers, (2) the most instructive part of the activities and (3) the most difficult part of the activities. Participants stated that activities provided important contributions regarding interdisciplinary view, and recalling chemistry subject matter knowledge and reinforcing them. In addition, the results of this study indicated that most of the activities have positive contributions to the interdisciplinary perspectives of the pre-service teachers, to their ability to relate chemistry subjects to everyday life, and to address the problems they face with an inquiry approach. Therefore, STEM activities can help pre-service teachers earn the basic principles of science education, as activities encourage them to learn through inquiry and research. Moreover, STEM activities are expected to contribute to the cultivation of individuals who are able to solve their daily problems and contribute to the needs of society by providing students with the opportunity to integrate different disciplines and focus on research, design, problem solving and teamwork skills to solve real life problems. These results are in line with other results in the field (Aslan-Tutak, Akaygün \& Tezsezen 2017; Eroğlu \& Bektaş, 2016). Participants 
also specified that research for designing and design steps are the most informative steps. Besides, it has been determined that the presentation and evaluation stages of the products presented are also instructive because they allow them to see their own deficiencies and see other ideas. The study conducted by Bozkurt-Altan, Yamak and Buluş-Kırıkkaya (2016) also revealed that these processes were evaluated by pre-service teachers as positive aspects of design-based science education. Finally, regarding the most difficult part of the activities, they mentioned that it was hard to decide the materials used, decide how to design, and research for necessary knowledge.

Conclusions and Recommendations: In order for the STEM approach to be implemented in schools, priority should be given to teacher education. As teacher educators, training teachers who understand STEM approach and its importance, and experienced it should be our priorities. At this point, it would be useful to provide elective courses based on design, creativity and engineering to teacher training programs. When previous experiences were considered, participants were forced to not use the acquired knowledge to make product or design. Therefore, these difficulties can be overcome with the presentation of the mentioned courses. In addition, in order to solve the problem of time constraint in general, the application of such activities as after-school program will reduce the concerns of the participants about their grade, and help them design and develop a product without worrying about time.

Keywords: Integrated STEM education, pre-service chemistry teachers, engineering design process, case study 